\title{
Evaluation of purine metabolites - creatinine index to predict the rumen microbial protein synthesis from urinary spot samples in Barbari goats*
}

\author{
S.K. George ${ }^{1,2}$, A.K. Verma ${ }^{1}$, U.R. Mehra ${ }^{1}$, M.T. Dipu ${ }^{1,2}$ and P. Singh ${ }^{1}$ \\ ${ }^{1}$ Indian Veterinary Research Institute, Animal Nutrition Division \\ Izatnagar, Uttar Pradesh 243 122, India \\ ${ }^{2}$ College of Veterinary and Animal Sciences, Mannuthy, Thrissur, \\ Kerala Veterinary and Animal Sciences University \\ Kerala 680 651, India
}

(Received 16 July 2011; revised version 19 September 2011; accepted 6 December 2011)

\begin{abstract}
The study evaluated the potential of the concentration of purine metabolites (PM) in spot urine as an alternative to performing a total urine collection to predict the microbial nitrogen (MN) supply in goats. The study was conducted in two phases. Phase I was comprised of fasting metabolism trial of eight goat bucks $(19.70 \pm 0.59 \mathrm{~kg}$ mean body weight $)$ to quantify the contribution of basal PM excretion. PM excretion decreased $(\mathrm{P}<0.05)$ with feed restriction and the mean value $(\mu \mathrm{mol} /$ $\mathrm{kgW}^{0.75} / \mathrm{d}$ ) observed during fasting was $250.09 \pm 5.11$. Phase II examined the response of PM excretion to feed intake and evaluated the usefulness of purine metabolites: creatinine (PMC) index in spot urine samples for prediction of rumen MN supply. The concentration of PM in total urine and spot urine was quantified in eight goat bucks $(20.24 \pm 0.74 \mathrm{~kg}$ mean body weight) allocated in two sets of $4 \times 4$ Latin square design at four fixed levels of feed intake $(95,80,60$ and $40 \%$ of voluntary feed intake) on diet based on wheat straw and concentrate mixture (50:50). Total PM excretion increased linearly with level of intake. Urinary excretion of creatinine did not differ among groups, while the PMC index calculated from total urine and spot urine increased $(\mathrm{P}<0.05)$ with level of feed intake. PMC index of spot urine differentiated the feeding levels at 6 and $12 \mathrm{~h}$ post feeding. The relationship between PMC index in the spot urine samples collected $12 \mathrm{~h}$ after the morning feed and the daily total PM excretion was the highest $\left(\mathrm{R}^{2}=0.82\right)$. The results confirm that PMC index in spot urine samples can serve as a potential tool for the quantification of MN supply in goats.
\end{abstract}

KEY WORDS: goats, feed intake, purine metabolites, microbial nitrogen, spot urine, creatinine index

\footnotetext{
* Supported by the NATP (CGP-III), ICAR, New Delhi

${ }^{2}$ Corresponding author: e-mail: skgeorge31@gmail.com
} 


\section{INTRODUCTION}

The methods generally used for determining rumen microbial protein synthesis depend on the use of natural microbial markers such as RNA (ribonucleic acid) and DAPA (diaminopimelic acid) or isotopes of ${ }^{35} \mathrm{~S},{ }^{15} \mathrm{~N}$ and ${ }^{32} \mathrm{P}$. The idea of using purine metabolites (PM: allantoin, uric acid, xanthine and hypoxanthine) as a specific marker for rumen microbial biomass was suggested by Topps and Elliot (1965). Purines in dietary materials are degraded rapidly by microbial enzymes in the rumen (Smith and McAllan, 1970) and they are, therefore, likely to be present in negligible concentration in digesta leaving the rumen. The microbial purines, on the other hand, remain intact in living microbial cells and pass via the abomasum to the small intestine where they are degraded enzymatically to nucleotides and purine bases which in turn get absorbed. Therefore, the amount of PM in the urine can be used to predict the flow of microbial purines into the duodenum, thus quantifying the intestinal absorption of amino acids of microbial origin (Verbic et al., 1990). The PM in urines samples can be easily estimated by colorimetric (Young and Conway, 1942) and chromatographic methods (Czauderna and Kowalczyk, 2000, 2004). The prediction of microbial protein using urinary PM has special interest since it overcomes the disadvantages of other conventional methods. This technique is non invasive and simple by avoiding the need for fistulated animals and those measurements related to digesta and microbial marker kinetics. However, the requirement of total urine collection limits the use of this technique in farm/field conditions. Therefore, a logical step forward would be to use the concentration of PM in spot urine samples as an index of microbial protein supply. A number of studies in ruminant species (Daniels et al., 1994; Chen et al., 1995) indicated that purine metabolites: creatinine (PMC) index can predict microbial nitrogen (MN) supply with reasonable accuracy as it is little affected by sampling time, while the data of Shingfield and Offer (1998) indicated a diurnal variation in the PMC index. There is a lack of information regarding the accuracy of spot sampling technique to assess the daily excretion of PM under practical feeding conditions in goats. Consequently, this study examined the influence of levels of feed intake on concentration of PM in urinary spot samples and evaluated the use of PMC in spot urine samples as an on farm diagnostic tool to estimate the MN supply in goats.

\section{MATERIAL AND METHODS}

The study was conducted in two phases. 


\section{Phase I: Feed restriction and fasting}

\section{Animals and management}

Eight adult Barbari goat bucks (19.70 $\pm 0.59 \mathrm{~kg}$ mean body weight) about 2 years old were used for this study. The animals were fed a mixed diet of wheat straw and concentrate (50:50) (Table 1) at maintenance level (NRC, 1981) for ten days (adaptation period) before starting the sampling period of 12 days $[100 \%$ of maintenance requirement of DM intake, i.e. $483 \mathrm{~g} /$ day (prior restriction) for 2 days, $60 \%$ of maintenance requirement (mild restriction) for 2 days, $30 \%$ of maintenance requirement (severe restriction) for 2 days and fasting for 6 days]. Animals were housed in metabolic cages during the sampling period to facilitate total collection of urine.

Table 1. Ingredients and chemical composition of the roughage and concentrate supplied to goats

\begin{tabular}{|c|c|c|}
\hline Item & Concentrate & Roughage \\
\hline \multicolumn{3}{|l|}{ Ingredients, \% } \\
\hline wheat straw & & 100 \\
\hline maize & 38 & \\
\hline wheat bran & 38 & \\
\hline soyabean meal & 22 & \\
\hline vitamin/mineral supplement ${ }^{1}$ & 2 & \\
\hline \multicolumn{3}{|l|}{ Chemical composition, \% DM basis } \\
\hline organic matter & 90.88 & 90.31 \\
\hline crude protein & 18.12 & 3.07 \\
\hline ether extract & 2.31 & 1.09 \\
\hline crude fibre & 8.34 & 37.48 \\
\hline neutral-detergent fibre & 42.70 & 81.03 \\
\hline acid-detergent fibre & 11.10 & 51.24 \\
\hline total ash & 9.12 & 9.69 \\
\hline
\end{tabular}

\section{Phase II: Feeding trial}

Animals, experimental design, diets and feeding

Eight adult Barbari goat bucks about two years old $(20.24 \pm 0.74 \mathrm{~kg}$ mean body weight) were used for this study. The animals were fed ad libitum a mixed diet of wheat straw and concentrate (50:50) individually for one week during the preliminary feeding period (Table 1). The lowest level of intake recorded during this period among all animals ( $484.47 \pm 0.05 \mathrm{~g} / \mathrm{d}$ on DM basis) was set as voluntary feed intake (VFI) to ensure that all animals were able to consume all the feed offered to them during the experimental feeding. 
Two sets of $4 \times 4$ Latin square design were used for this experiment. The experiment consisted of four 21- day feeding periods and four feeding levels. The highest level of intake was $95 \%$ of VFI (Group I). The other 3 levels were $80 \%$ (Group II), 60\% (Group III) and 40\% (Group IV) of the voluntary intake. The animals were weighed (before feeding and watering) at the beginning and end of each period to record liveweight changes during the study. During last 8 days of each period, total urine excreted and faeces voided were collected daily. Spot urine collections were performed during last two days of the metabolism trial, for which each day $(24 \mathrm{~h})$ was divided into four sampling periods, each comprising a time interval of $6 \mathrm{~h}$, starting immediately before feeding (designated as $0 \mathrm{~h}$ ). The first urine excreted by animals in each sampling period was collected and a fixed sample $(20 \mathrm{ml})$ was transferred into plastic vials (containing $2 \mathrm{ml}$ of $10 \%$ $\mathrm{H}_{2} \mathrm{SO}_{4}$ ). The samples of feed, faeces and urine collected during the metabolism trial were processed and stored following approved protocols (IAEA-TECDOC945, 1997).

\section{Measurements and chemical analysis}

Measurement of apparent digestibility of dry matter (DM) and organic matter (OM) was calculated from the total faeces collection. A sample of each daily faecal collection was homogenized, weighed and dried to estimate total faecal DM production. The DM and OM contents of feeds and faeces were estimated according to AOAC (1995) methods. Urinary allantoin was determined colorimetrically by the method of Young and Conway (1942). Uric acid in urine was determined colorimetrically by phosphotungstic acid method using a commercial kit (Span Diagnostics ${ }^{\circledR}$, India) and the salvageable PM (hypoxanthine and xanthine) were analysed by the enzymatic method according to the procedure of Chen and Gomes (1992). Creatinine was analysed based on the Jaffe alkaline picrate reaction using a commercial kit (Qualigens ${ }^{\circledR}$, India).

\section{Calculations and statistical analysis}

The amount of microbial purines absorbed (X, mmol/d) corresponding to the PM excreted (Y, mmol/d) was estimated following suitable modifications in curvilinear model of Chen et al. (1990a) in intragastric fed sheep:

$$
\mathrm{Y}=0.84 \mathrm{X}+\left(0.150 \mathrm{~W}^{0.75} \mathrm{e}^{-0.25 x}\right)
$$

were: 0.84 - the recovery of absorbed purines as PM in urine, 0.150 - endogenous urinary PM contribution, $\mathrm{W}^{0.75}$ - the metabolic body weight $(\mathrm{kg})$ of animal, as follows: 


$$
\mathrm{X}=\mathrm{Y}-\left(\mathrm{EPM} \mathrm{W}^{0.75} \mathrm{e}^{-0.25 \mathrm{x}}\right) / 0.74
$$

where: $\mathrm{X}$ - microbial purines absorbed $(\mathrm{mmol} / \mathrm{d}), \mathrm{Y}$ - urinary PM excretion $(\mathrm{mmol} / \mathrm{d}), \mathrm{EPM}$ - the endogenous urinary PM excretion obtained from the Phase I of the present study. The slope of 0.74 in equation represents the recovery of absorbed purines as PM in urine of goats (Mota et al., 2008).

The supply of MN (g/d) was estimated as follows, from the relationship derived by Chen and Gomes (1992):

$$
\mathrm{MN}(\mathrm{g} / \mathrm{d})=70 \mathrm{X} /(0.116 \times 0.83 \times 1000)=0.727 \mathrm{X}
$$

where: $\mathrm{X}$ - microbial purines absorbed (mmol/d).

The assumptions made in the above equations are:

i) digestibility of microbial purines is assumed to be 0.83 . This is taken as the mean digestibility value for microbial nucleic acids on observations reported in the literature

ii) the $\mathrm{N}$ content of purines is $70 \mathrm{mg} \mathrm{N} / \mathrm{mmol}$

iii) the ratio of purine $\mathrm{N}$ : total $\mathrm{N}$ in mixed rumen microbes is taken as 11.6:100.

PMC index was estimated as follows:

$$
\mathrm{PMC} \text { index }=\mathrm{PM} \times \mathrm{W}^{0.75} / \text { creatinine }
$$

where: $\mathrm{W}^{0.75}$ - the metabolic body weight $(\mathrm{kg})$ of the animal, PM and creatinine concentration $(\mathrm{mmol} / \mathrm{l})$ in urine.

Digestible organic matter apparently fermented in the rumen (DOMR) was calculated from the relationship derived by Chen and Gomes (1992):

$$
\begin{aligned}
\text { DOMR }=\text { feed intake } & \times \text { DM content }(\% / 100) \times \text { OM content }(\% / 100) \\
& \times \text { OM digestibility }(\% / 100) \times 0.65
\end{aligned}
$$

The various data sets were subjected to analyses of variance (ANOVA) procedure according to a Latin square design using the General Linear Model (GLM) of the SAS system for Windows (1995). Treatment means were compared by using Duncan's New Multiple Range Test. The statistical model is shown below:

$$
\mathrm{Y}=\mu+\alpha+\beta+\gamma(\alpha)+t+\varepsilon
$$

where: $\mu$ - the overall mean, $\alpha$ - the random effect of the square, $\beta$ - the random effect of period, $\gamma(\alpha)$ - the random effect of goat within the square, $t$ - the fixed effect of treatment, $\varepsilon$ - the random error. 
The excretion rates of urinary PM in Phase II were regressed against their respective DM and digestible OM intake using linear regression analysis.

\section{RESULTS}

\section{Phase I: Feed restriction and fasting}

\section{Endogenous PM excretion}

The goats used for estimation of endogenous excretion of PM remained in good health during this phase. The average values for the daily excretion of PM and creatinine by goats recorded during feed restriction and fasting periods are given in Table 2. Allantoin excretion decreased $(\mathrm{P}<0.01)$ during mild and severe feed restriction and the basal excretion $\left(\mu \mathrm{mol} / \mathrm{kgW}^{0.75} / \mathrm{d}\right)$ averaged $165.16 \pm 3.39$ during fasting. Total PM excretion, which was mainly present as allantoin, decreased $(\mathrm{P}<0.01)$ to lower and constant value during last four days of feed restriction. The average relative contribution of allantoin to total PM decreased from 81.69 (prior-feed restriction) to $66.37 \%$ during fasting, whereas the proportion of uric acid and salvageable PM (xanthine and hypoxanthine) increased while fasting.

Table 2. Daily urinary excretion of purine metabolites (PM) and creatinine during pre-fasting and fasting

\begin{tabular}{|c|c|c|c|c|c|}
\hline \multirow[b]{2}{*}{ Parameters } & \multicolumn{4}{|c|}{ Feed restrictions } & \multirow[b]{2}{*}{ SEM } \\
\hline & no restriction & $\begin{array}{c}\text { mild } \\
\text { restriction }\end{array}$ & $\begin{array}{c}\text { severe } \\
\text { restriction }\end{array}$ & fasting & \\
\hline \multicolumn{6}{|l|}{ Allantoin } \\
\hline $\mathrm{mmol} / \mathrm{d}^{* *}$ & $5.98^{\mathrm{a}}$ & $4.44^{\mathrm{b}}$ & $3.35^{\mathrm{c}}$ & $1.48^{\mathrm{d}}$ & 0.23 \\
\hline$\mu \mathrm{mol} / \mathrm{kgW}^{0.75} / \mathrm{d}^{* *}$ & $642.82^{\mathrm{a}}$ & $476.41^{b}$ & $359.09^{c}$ & $165.16^{\mathrm{d}}$ & 29.31 \\
\hline \multicolumn{6}{|l|}{ Uric acid } \\
\hline $\mathrm{mmol} / \mathrm{d}^{* *}$ & $0.71^{\mathrm{a}}$ & $0.66^{\mathrm{a}}$ & $0.63^{\mathrm{a}}$ & $0.42^{\mathrm{b}}$ & 0.04 \\
\hline$\mu \mathrm{mol} / \mathrm{kgW}^{0.75} / \mathrm{d}^{* *}$ & $76.14^{\mathrm{a}}$ & $70.98^{\mathrm{a}}$ & $67.15^{\mathrm{a}}$ & $46.84^{\mathrm{b}}$ & 4.65 \\
\hline \multicolumn{6}{|c|}{ Xanthine and hypoxanthine } \\
\hline $\mathrm{mmol} / \mathrm{d}^{* *}$ & $0.62^{\mathrm{a}}$ & $0.57^{\mathrm{ab}}$ & $0.52^{\mathrm{b}}$ & $0.34^{\mathrm{c}}$ & 0.04 \\
\hline$\mu \mathrm{mol} / \mathrm{kgW}^{0.75} / \mathrm{d}^{*}$ & $66.69^{a}$ & $61.28^{\mathrm{ab}}$ & $55.40^{\mathrm{b}}$ & $38.09^{c}$ & 4.25 \\
\hline \multicolumn{6}{|l|}{ Total PM } \\
\hline $\mathrm{mmol} / \mathrm{d}^{* *}$ & $7.32^{\mathrm{a}}$ & $5.67^{\mathrm{b}}$ & $4.49^{\mathrm{c}}$ & $2.23^{\mathrm{d}}$ & 0.23 \\
\hline$\mu \mathrm{mol} / \mathrm{kgW}^{0.75} / \mathrm{d}^{* *}$ & $685.65^{\mathrm{a}}$ & $608.66^{\mathrm{b}}$ & $481.64^{c}$ & $250.09^{d}$ & 30.04 \\
\hline \multicolumn{6}{|l|}{ Creatinine } \\
\hline $\mathrm{mmol} / \mathrm{d}^{* *}$ & $4.02^{\mathrm{b}}$ & $4.14^{\mathrm{b}}$ & $4.37^{\mathrm{a}}$ & $4.56^{\mathrm{a}}$ & 0.11 \\
\hline$\mu \mathrm{mol} / \mathrm{kgW}^{0.75} / \mathrm{d}^{* *}$ & $431.38^{\mathrm{b}}$ & $443.88^{\mathrm{b}}$ & $469.85^{\mathrm{b}}$ & $511.71^{\mathrm{a}}$ & 18.58 \\
\hline
\end{tabular}


The data from the last four days of fasting period were taken as the endogenous $\mathrm{PM}$ excretion and the mean value ( $\left.\mu \mathrm{mol} / \mathrm{kgW}^{0.75} / \mathrm{d}\right)$ was $250.09 \pm 5.11$ (Figure 1). The excretion rates of creatinine remained similar up to $60 \%$ of maintenance feeding, but increased $(\mathrm{P}<0.01)$ by further feed restriction.

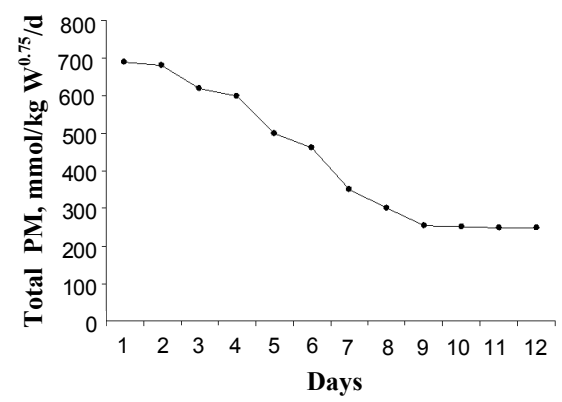

Figure.1. Excretion of urinary purine metabolites (PM) during feed restriction and fasting

\section{Phase II: Feeding trial}

\section{Nutrient intake and digestibility}

The feeds offered did not vary throughout the experiment, so it has been concluded that the difference observed for digestive events could be attributed to the effects of intake changes. Mean body weight, feed intake (DM and OM) and the apparent digestibility of DM and OM are given in Table 3. The DM and OM intakes were different $(\mathrm{P}<0.01)$ among the treatment groups as envisaged by the experimental design. The mean digestibility of $\mathrm{DM}$ and $\mathrm{OM}$ was higher $(\mathrm{P}<0.05)$ in groups I (L-95) and II (L-80) as compared with group IV (L-40).

Table 3. Mean body weight, dry matter (DM) intake, digestible DM (DDM) intake, organic matter $(\mathrm{OM})$ intake, digestible OM (DOM) intake and apparent digestibility of DM and OM in different groups

\begin{tabular}{lccccc}
\hline Parameters & $\begin{array}{c}\text { Group I } \\
(\text { L-95) }\end{array}$ & $\begin{array}{c}\text { Group II } \\
(\mathrm{L}-80)\end{array}$ & $\begin{array}{c}\text { Group III } \\
(\mathrm{L}-60)\end{array}$ & $\begin{array}{c}\text { Group IV } \\
(\mathrm{L}-40)\end{array}$ & SEM \\
\hline Body weight, kg & 21.09 & 20.63 & 19.86 & 19.16 & 1.00 \\
Intake, g/d & & & & & \\
$\quad \mathrm{DM}^{* *}$ & $459.50^{\mathrm{a}}$ & $385.98^{\mathrm{b}}$ & $294.08^{\mathrm{c}}$ & $192.99^{\mathrm{d}}$ & 0.90 \\
$\mathrm{DDM}^{* *}$ & $274.78^{\mathrm{a}}$ & $226.15^{\mathrm{b}}$ & $169.55^{\mathrm{c}}$ & $106.05^{\mathrm{d}}$ & 4.86 \\
OM $^{* *}$ & $416.28^{\mathrm{a}}$ & $349.67^{\mathrm{b}}$ & $266.42^{\mathrm{c}}$ & $174.84^{\mathrm{d}}$ & 0.81 \\
DOM $^{* *}$ & $265.34^{\mathrm{a}}$ & $218.85^{\mathrm{b}}$ & $164.39^{\mathrm{c}}$ & $103.47^{\mathrm{d}}$ & 4.05 \\
Digestibility, \% & & & & & \\
DM $^{*}$ & & & & & \\
OM1 $^{*}$ & $59.80^{\mathrm{a}}$ & $58.59^{\mathrm{a}}$ & $57.65^{\mathrm{ab}}$ & $54.95^{\mathrm{b}}$ & 1.60 \\
\hline
\end{tabular}

values with different letters in a row differ significantly: ${ }^{*} \mathrm{P}<0.05,{ }^{* *} \mathrm{P}<0.01$ 


\section{$P M$ and creatinine excretion at different levels of feed intake}

The variations in daily urinary excretions of PM and creatinine at different levels of intake are presented in Table 4. The PM excretion responded significantly $(\mathrm{P}<0.05)$ to intake of $\mathrm{DM}$ and DOM. This increase was mainly explained by the significant response in allantoin excretion with regard to feed intake. The urinary excretion of uric acid and salvageable PM $(\mathrm{mmol} / \mathrm{d})$ was higher $(\mathrm{P}<0.05)$ in group I when compared with groups III and IV. However, when expressed in terms of metabolic body weight the values did not vary among dietary levels. Urinary excretion of creatinine did not differ $(\mathrm{P}>0.05)$ among groups. However, when expressed in terms of metabolic body weight, the values were higher $(\mathrm{P}<0.05)$ in group IV compared with group I. The $\mathrm{PMC}$ index of total urine decreased $(\mathrm{P}<0.05)$ with the reduction in feed intake (Table 4).

Table 4. Excretion of urinary purine metabolites (PM), creatinine, PMC index and microbial nitrogen synthesis at different levels of feed intake

\begin{tabular}{|c|c|c|c|c|c|}
\hline Parameters & $\begin{array}{c}\text { Group I } \\
\text { (L-95) }\end{array}$ & $\begin{array}{c}\text { Group II } \\
(\mathrm{L}-80)\end{array}$ & $\begin{array}{c}\text { Group III } \\
(\mathrm{L}-60)\end{array}$ & $\begin{array}{c}\text { Group IV } \\
(\mathrm{L}-40)\end{array}$ & SEM \\
\hline \multicolumn{6}{|l|}{ Allantoin } \\
\hline $\mathrm{mmol} / \mathrm{d}^{* *}$ & $5.36^{\mathrm{a}}$ & $4.31^{\mathrm{b}}$ & $3.10^{\mathrm{c}}$ & $2.07^{\mathrm{d}}$ & 0.34 \\
\hline $\mathrm{mmol} / \mathrm{kgW}^{0.75} / \mathrm{d}^{*}$ & $0.54^{\mathrm{a}}$ & $0.45^{\mathrm{b}}$ & $0.33^{\mathrm{c}}$ & $0.23^{\mathrm{d}}$ & 0.04 \\
\hline \multicolumn{6}{|l|}{ Uric acid } \\
\hline $\mathrm{mmol} / \mathrm{d}^{*}$ & $0.64^{\mathrm{a}}$ & $0.60^{\mathrm{ab}}$ & $0.56^{\mathrm{b}}$ & $0.55^{\mathrm{b}}$ & 0.03 \\
\hline $\mathrm{mmol} / \mathrm{kgW}^{0.75} / \mathrm{d}$ & 0.066 & 0.063 & 0.061 & 0.059 & 0.005 \\
\hline \multicolumn{6}{|c|}{ Xanthine and hypoxanthine } \\
\hline $\mathrm{mmol} / \mathrm{d}^{*}$ & $0.53^{\mathrm{a}}$ & $0.49^{\mathrm{ab}}$ & $0.45^{\mathrm{b}}$ & $0.44^{\mathrm{b}}$ & 0.03 \\
\hline $\mathrm{mmol} / \mathrm{kgW}^{0.75} / \mathrm{d}$ & 0.054 & 0.053 & 0.049 & 0.049 & 0.005 \\
\hline \multicolumn{6}{|l|}{ Total PM } \\
\hline $\mathrm{mmol} / \mathrm{d}^{* *}$ & $6.52^{\mathrm{a}}$ & $5.41^{\mathrm{b}}$ & $4.11^{\mathrm{c}}$ & $3.05^{\mathrm{d}}$ & 0.35 \\
\hline $\mathrm{mmol} / \mathrm{kgW}^{0.75} / \mathrm{d}^{*}$ & $0.66^{\mathrm{a}}$ & $0.57^{\mathrm{b}}$ & $0.44^{\mathrm{c}}$ & $0.33^{\mathrm{d}}$ & 0.04 \\
\hline \multicolumn{6}{|l|}{ Creatinine } \\
\hline $\mathrm{mmol} / \mathrm{d}$ & 4.02 & 4.05 & 4.10 & 4.20 & 0.14 \\
\hline $\mathrm{mmol} / \mathrm{kgW}^{0.75} / \mathrm{d}^{*}$ & $0.41^{\mathrm{b}}$ & $0.42^{\mathrm{ab}}$ & $0.44^{\mathrm{ab}}$ & $0.46^{\mathrm{a}}$ & 0.02 \\
\hline$P M C$ index ${ }^{*}$ & $16.12^{\mathrm{a}}$ & $12.95^{\mathrm{b}}$ & $9.41^{\mathrm{c}}$ & $6.70^{\mathrm{d}}$ & 1.12 \\
\hline \multicolumn{6}{|l|}{ MN supply } \\
\hline $\mathrm{g} / \mathrm{d}^{*}$ & $5.92^{\mathrm{a}}$ & $4.72^{\mathrm{b}}$ & $3.09^{c}$ & $1.64^{\mathrm{d}}$ & 0.45 \\
\hline $\mathrm{g} / \mathrm{kg} \mathrm{DOMI}^{*}$ & $22.34^{\mathrm{a}}$ & $21.57^{\mathrm{ab}}$ & $18.98^{\mathrm{ab}}$ & $15.79^{\mathrm{b}}$ & 2.82 \\
\hline $\mathrm{g} / \mathrm{kg} \mathrm{DOMR}^{*}$ & $34.37^{\mathrm{a}}$ & $33.19^{\mathrm{ab}}$ & $29.20^{\mathrm{ab}}$ & $24.29^{\mathrm{b}}$ & 4.33 \\
\hline
\end{tabular}

DOMI - digestible organic matter intake; DOMR - digestible organic matter fermented in rumen values with different letters in a row differ significantly: ${ }^{*} \mathrm{P}<0.05,{ }^{* *} \mathrm{P}<0.01$ 


\section{Microbial nitrogen supply}

Based on the PM excretion rates during Phase I and at different levels of feed intake (Phase II), the relationship between daily urinary PM excretion (Y mmol) and daily MN supply (X mmol) was developed in the present study for goats as:

$$
\mathrm{Y}=0.74 \mathrm{X}+\left(0.250 \mathrm{~kg} \mathrm{~W}^{0.75} \mathrm{e}^{-0.25 x}\right)
$$

where: 0.250 - the endogenous contribution of PM observed in the present study and the slope of 0.74 in equation represents the recovery of absorbed purines as PM in urine (Mota et al., 2008).

The estimated MN supply to goats, at different levels of feed intake, is given in Table 4. The MN supply was highest $(\mathrm{P}<0.05)$ in animals at intake level L-95 and decreased $(\mathrm{P}<0.05)$ linearly with corresponding reduction in feed intake. Similarly, the efficiency of MN supply ( $\mathrm{g} / \mathrm{kg}$ DOMI or $\mathrm{g} / \mathrm{kg}$ DOMR) remained higher $(\mathrm{P}<0.05)$ at increased level of feed intake.

\section{PMC index in spot urine samples}

The mean concentration of PM and creatinine in spot urine samples of goats collected over four periods at $6 \mathrm{~h}$ intervals at different levels is summarized in Table 5. Although a significant $(\mathrm{P}<0.01)$ effect of dietary level of feed was evident on mean concentration of allantoin between groups I (L-95), III (L-60) and IV (L-40), the values of group II were similar $(\mathrm{P}>0.05)$ as compared with groups I and III. The mean concentration of uric acid and salvageable PM in spot urine samples was higher $(\mathrm{P}<0.05)$ in groups I and II as compared with group IV. The total PM concentration in spot urine samples followed a similar pattern as that of allantoin. The mean level of creatinine in spot samples of animals with group IV was higher $(\mathrm{P}<0.01)$ as compared with its relative concentrations in groups I and II. Calculated PMC index of spot urine samples responded significantly $(\mathrm{P}<0.01)$ to level of feed intake.

Table 5. Mean concentration (mmol/l) of purine metabolites (PM) and creatinine in spot urine samples and PMC index at different levels of feed intake in various groups

\begin{tabular}{lccccc}
\hline Parameters & $\begin{array}{c}\text { Group I } \\
(\text { L-95) }\end{array}$ & $\begin{array}{c}\text { Group II } \\
(\text { L-80) }\end{array}$ & $\begin{array}{c}\text { Group III } \\
(\text { L-60) }\end{array}$ & $\begin{array}{c}\text { Group IV } \\
(\text { L-40) }\end{array}$ & SEM \\
\hline Allantoin & $7.40^{\mathrm{a}}$ & $6.62^{\mathrm{ab}}$ & $5.96^{\mathrm{b}}$ & $4.68^{\mathrm{c}}$ & 0.51 \\
Uric acid & $0.79^{\mathrm{a}}$ & $0.73^{\mathrm{a}}$ & $0.68^{\mathrm{ab}}$ & $0.55^{\mathrm{b}}$ & 0.06 \\
Xanthine and hypoxanthine & $0.61^{\mathrm{a}}$ & $0.56^{\mathrm{a}}$ & $0.52^{\mathrm{ab}}$ & $0.45^{\mathrm{b}}$ & 0.05 \\
Total PM & $8.80^{\mathrm{a}}$ & $7.92^{\mathrm{ab}}$ & $7.15^{\mathrm{b}}$ & $5.68^{\mathrm{c}}$ & 0.60 \\
Creatinine & $5.67^{\mathrm{c}}$ & $5.92^{\mathrm{bc}}$ & $6.66^{\mathrm{ab}}$ & $7.32^{\mathrm{a}}$ & 0.43 \\
PMC index & $15.39^{\mathrm{a}}$ & 13.16 & $10.02^{\mathrm{c}}$ & $7.11^{\mathrm{d}}$ & 0.43 \\
\hline
\end{tabular}

values with different letters in a row differ significantly: $\mathrm{P}<0.05, \mathrm{P}<0.01$ 
The $6 \mathrm{~h}$ variations observed in concentration of PM, creatinine and the calculated PMC index are presented in Table 6. Concentration of allantoin in spot urine samples collected at different hours post-feeding was relatively higher $(\mathrm{P}<0.05)$ at increased levels of feed intake except for $18 \mathrm{~h}$, which had comparable values. The level of uric acid and salvageable PM in the urine were higher at a better plane of nutrition during 0 and $6 \mathrm{~h}$ post-feeding. Concentration of total PM in spot urine samples differentiated the dietary levels to a certain extent up to $12 \mathrm{~h}$ post-feeding; however the values were similar $(\mathrm{P}>0.05)$ in all the groups at $18 \mathrm{~h}$ post-feeding. Concentration of creatinine was unaffected by

Table 6. Concentration ( $\mathrm{mmol} / \mathrm{l}$ ) of allantoin, uric acid, salvageable PM (xanthine and hypoxanthine) and creatinine and values of PMC index in various groups at different hours post-feeding

\begin{tabular}{|c|c|c|c|c|}
\hline \multirow{2}{*}{ Groups $^{1}$} & \multicolumn{4}{|c|}{ Period, $\mathrm{h}$} \\
\hline & $0(9.00)$ & $6(15.00)$ & $12(21.00)$ & $18(3.00)$ \\
\hline \multicolumn{5}{|l|}{ Allantoin } \\
\hline I & $7.61 \pm 0.34^{\mathrm{a}}$ & $8.06 \pm 0.60^{\mathrm{a}}$ & $8.11 \pm 1.22^{\mathrm{a}}$ & $5.84 \pm 0.87$ \\
\hline II & $6.68 \pm 0.38^{\mathrm{a}}$ & $6.71 \pm 0.64^{\mathrm{ab}}$ & $7.21 \pm 0.82^{\mathrm{ab}}$ & $5.90 \pm 0.65$ \\
\hline III & $5.05 \pm 0.31^{\mathrm{b}}$ & $6.34 \pm 0.91^{\mathrm{ab}}$ & $6.74 \pm 0.67^{\mathrm{ab}}$ & $5.71 \pm 0.93$ \\
\hline IV & $3.85 \pm 0.38^{c}$ & $4.63 \pm 0.65^{b}$ & $4.70 \pm 0.59^{b}$ & $5.53 \pm 0.86$ \\
\hline \multicolumn{5}{|l|}{ Uric acid } \\
\hline I & $0.87 \pm 0.06^{\mathrm{a}}$ & $0.90 \pm 0.07^{\mathrm{a}}$ & $0.67 \pm 0.09$ & $0.73 \pm 0.12$ \\
\hline II & $0.75 \pm 0.05^{\mathrm{a}}$ & $0.75 \pm 0.09^{\mathrm{ab}}$ & $0.75 \pm 0.09$ & $0.69 \pm 0.08$ \\
\hline III & $0.59 \pm 0.04^{\mathrm{b}}$ & $0.65 \pm 0.09^{\mathrm{bc}}$ & $0.79 \pm 0.14$ & $0.66 \pm 0.11$ \\
\hline IV & $0.43 \pm 0.04^{c}$ & $0.50 \pm 0.06^{c}$ & $0.65 \pm 0.14$ & $0.62 \pm 0.08$ \\
\hline \multicolumn{5}{|c|}{ Xanthine and hypoxanthine } \\
\hline I & $0.70 \pm 0.06^{\mathrm{a}}$ & $0.63 \pm 0.04^{\mathrm{a}}$ & $0.59 \pm 0.09$ & $0.53 \pm 0.09$ \\
\hline II & $0.58 \pm 0.04^{\mathrm{a}}$ & $0.54 \pm 0.05^{\mathrm{a}}$ & $0.55 \pm 0.07$ & $0.58 \pm 0.07$ \\
\hline III & $0.42 \pm 0.04^{\mathrm{b}}$ & $0.55 \pm 0.09^{\mathrm{a}}$ & $0.54 \pm 0.08$ & $0.56 \pm 0.09$ \\
\hline IV & $0.35 \pm 0.04^{\mathrm{b}}$ & $0.36 \pm 0.04^{b}$ & $0.53 \pm 0.12$ & $0.56 \pm 0.09$ \\
\hline \multicolumn{5}{|l|}{ Total PM } \\
\hline I & $9.18 \pm 0.42^{\mathrm{a}}$ & $9.58 \pm 0.69^{\mathrm{a}}$ & $9.37 \pm 1.30^{\mathrm{a}}$ & $7.10 \pm 1.07$ \\
\hline II & $8.01 \pm 0.43^{\mathrm{a}}$ & $7.99 \pm 0.78^{\mathrm{a} b}$ & $8.51 \pm 0.95^{\mathrm{ab}}$ & $7.17 \pm 0.79$ \\
\hline III & $6.06 \pm 0.37^{\mathrm{b}}$ & $7.54 \pm 1.08^{\mathrm{ab}}$ & $8.07 \pm 0.87^{\mathrm{ab}}$ & $6.93 \pm 1.12$ \\
\hline IV & $4.62 \pm 0.45^{\mathrm{c}}$ & $5.48 \pm 0.74^{b}$ & $5.88 \pm 0.77^{b}$ & $6.71 \pm 0.99$ \\
\hline \multicolumn{5}{|c|}{ Creatinine } \\
\hline I & $6.07 \pm 0.56$ & $5.87 \pm 0.31$ & $6.18 \pm 0.81$ & $4.56 \pm 0.57^{\mathrm{c}}$ \\
\hline II & $5.67 \pm 0.21$ & $5.77 \pm 0.60$ & $6.78 \pm 0.72$ & $5.45 \pm 0.58^{\mathrm{bc}}$ \\
\hline III & $5.77 \pm 0.35$ & $6.72 \pm 0.64$ & $7.81 \pm 0.60$ & $6.34 \pm 0.63^{\mathrm{b}}$ \\
\hline IV & $6.38 \pm 0.68$ & $6.92 \pm 0.65$ & $7.88 \pm 0.62$ & $8.08 \pm 0.61^{\mathrm{a}}$ \\
\hline \multicolumn{5}{|c|}{$P M C$ index } \\
\hline I & $15.26 \pm 0.66^{\mathrm{a}}$ & $16.08 \pm 0.83^{\mathrm{a}}$ & $14.98 \pm 0.81^{\mathrm{a}}$ & $15.25 \pm 0.98^{a}$ \\
\hline II & $13.67 \pm 0.59^{\mathrm{a}}$ & $13.68 \pm 0.71^{\mathrm{b}}$ & $12.38 \pm 0.72^{\mathrm{b}}$ & $12.93 \pm 0.90^{\mathrm{a}}$ \\
\hline III & $9.88 \pm 0.32^{\mathrm{b}}$ & $10.49 \pm 0.93^{c}$ & $9.64 \pm 0.60^{\mathrm{c}}$ & $10.05 \pm 0.95^{\mathrm{b}}$ \\
\hline IV & $6.87 \pm 0.69^{\mathrm{c}}$ & $7.34 \pm 0.75^{\mathrm{d}}$ & $6.75 \pm 0.57^{\mathrm{d}}$ & $7.49 \pm 0.83^{\mathrm{b}}$ \\
\hline
\end{tabular}

values with different letters in a column differ significantly $(\mathrm{P}<0.05)$

${ }^{1}$ explanation see Table 3 
levels of feed intake. However, the values remained higher $(\mathrm{P}<0.05)$ at a lower plane of nutrition at $18 \mathrm{~h}$ post-feeding. Interestingly, PMC index of spot urine samples could differentiate the dietary treatments at different hours post-feeding and the treatment effect was more pronounced at 6 and $12 \mathrm{~h}$ post-feeding.

\section{DISCUSSION}

\section{Phase I: Feed restriction and fasting}

Endogenous PM excretion. Although urinary PM is derived mainly from the nucleic acids of rumen microbes digested in the lower gut, there is some endogenous contribution which must be assessed quantitatively if urinary $\mathrm{PM}$ is to be used as an index of microbial protein supply in ruminants. Chen et al. (1990a) hypothesized that the endogenous contribution of PM decreased as the supply of exogenous purines increased, with an associated progressive replacement of de novo synthesis from exogenous sources. In fasting, evidence does not exist that duodenal flow of purine bases is stopped, although this would be the method of choice to reduce exogenous rumen output of PM when no other methodology is available. In the present experiment this value, $250 \mu \mathrm{mol} / \mathrm{kgW}^{0.75} / \mathrm{d}$, was considered as the endogenous contribution to urinary excretion of PM, assuming that duodenal flow of purine bases would represent only a minor fraction (Ojeda and Parra, 1999). The endogenous PM excretion in the animals during this trial was comparable to that $\left(202-268.5 \mu \mathrm{mol} / \mathrm{kg} \mathrm{W}^{0.75} / \mathrm{d}\right)$ given in Granadina goats (Mota et al., 2008). Similar values were reported by Lindberg (1989) in goat kids $\left(242 \mu \mathrm{mol} / \mathrm{kg} \mathrm{W}^{0.75} / \mathrm{d}\right)$, with the principal proportion of allantoin $(60 \%)$. In the present study the relative contribution of allantoin to total PM decreased during fasting (66\%) when compared to pre-fasting $(82 \%)$. In Saanen goats, Fujihara et al. (2003) reported that urinary allantoin excretion decreased during fasting, and the average value was $180 \mu \mathrm{mol} / \mathrm{kgW}^{0.75} / \mathrm{d}$ during the fasting period of 8 days. In sheep, endogenous PM values $(130 \mu \mathrm{mol} / \mathrm{kg}$ $\mathrm{W}^{0.75} / \mathrm{d}$ ) obtained in fasting animals (Fujihara et al., 2003) are slightly lower when compared with goats. In general the endogenous PM excretion in small ruminants is much lower than those (443 to 514) observed in steers (Fujihara et al., 1987) and in cows (Chen et al., 1990b). However, Dipu et al. (2006) reported much lower value in Murrah buffaloes $\left(117 \mu \mathrm{mol} / \mathrm{kg} \mathrm{W}^{0.75} / \mathrm{d}\right)$. It is suggested that the lower value in buffaloes is due to a lower glomerular filtration rate as PM will stay longer in the blood and thus provide a greater possibility for recycling to the rumen (Thanh et al., 2009). The species variation is also attributed to difference in the xanthine oxidase state, the enzyme is absent in the blood of sheep and goat, 
but present in high activities in the blood and other tissues of cattle. Therefore, in goats, exogenous (microbial) purine bases can pass through the wall of the gastrointestinal tract and become available for direct incorporation into tissue nucleotides by the purine salvage pathway.

It is generally presumed that excretion rate of creatinine is relatively constant in healthy animals and remains independent of level of feed intake. However, in the present study, reduction in feed intake to $30 \%$ of the maintenance requirement or lower (fasting) resulted in increased $(\mathrm{P}<0.05)$ excretion of urinary creatinine. This might be due to increased degradation of phosphocreatine in muscle tissues, due to lack of available energy sources to meet the vital functions of animals during feed restriction. In a similar study in sheep, creatinine excretion rate remained higher for intakes of 0.5 times maintenance when compared with maintenance and above maintenance levels (Liu and McMeniman, 2006).

\section{Phase II: Feeding trial}

Nutrient intake and digestibility. Digestibility of a feed is not a fixed trait but is modified by various factors such as the level of feed intake, age, stage and level of animal production. Restriction of feed intake often results in enhanced OM digestibility owing to higher retention time in the rumen (Galyean and Owens, 1991). The decrease in feed intake did not induce increased DM and OM digestibility in the present study, probably due to lower availability of energy under restricted feeding conditions, which limits the growth of microorganisms (Dehority and Orpin, 1988). In Corriedale lambs, digestibility of OM tended to increase $(\mathrm{P}<0.05)$ with an increase in dietary energy (Fujihara et al., 2005). A similar type of variation in digestibility was also observed by Liu and McMeniman (2006) in Merino sheep. Contrary to this, comparable digestibility of DM and OM was recorded by Agabriel et al. (1995) at intakes lower than maintenance.

Response of PM and creatinine excretion to levels offeed intake. Positive linear relationships between intakes of digestible DM and urinary PM excretion (Vercoe, 1976) or digestible OM and urinary PM excretion or net microbial synthesis have been described for goat (Lindberg, 1985), sheep (Balcells et al., 1993) and cattle (Liang et al., 1994). The regression equations developed based on the results of this experiment suggest that urinary PM excretion is closely related with DMI and digestible OM intake (DOMI).

The relationship between PM excretion (Y; mmol/d) to DMI $(\mathrm{X} ; \mathrm{kg} / \mathrm{d})$ is as follows: $\mathrm{Y}=13.12 \mathrm{X}+0.40\left(\mathrm{R}^{2}=0.80\right)$.

The relationship between PM excretion (Y; mmol/d) to DOMI (X; $\mathrm{kg} / \mathrm{d})$ is as 
follows: $\mathrm{Y}=21.31 \mathrm{X}+0.77\left(\mathrm{R}^{2}=0.79\right)$.

The equation confirms the linear relationship between DOMI $(\mathrm{kg} / \mathrm{d})$ and the urinary excretion of PM $(\mathrm{mmol} / \mathrm{d})$ and the slope $(21.31 \mathrm{mmol} / \mathrm{kg}$ DOMI $)$ represents the efficiency coefficient for net microbial synthesis. The calculated value for goats in the present study is close to that reported for sheep (18.9-22.3) by Balcells et al. (1993) and in crossbred cattle (24.2) by George et al. (2006) but lower than the value (12.6) reported for goats (Laurent et al., 1983). Use of different diets in the different experiments as well as species variation might have contributed to part of the difference in the rate of PM excretion per unit DOMI.

Variations in PM excretion were accounted for by allantoin, the principal PM, whose relative proportion decreased from 82 (L-95) to 68\% (L-40). This observation is in agreement with a relatively lower contribution of allantoin to total PM during fasting (66\%) when compared with pre-fasting $(82 \%)$ as observed in the Phase I of the present experiment. The values observed in the present study are quite comparable to those reported earlier (Lindberg, 1985) in dairy goats. However, in a similar study in crossbred bulls (George et al., 2006) the relative contribution of allantoin and uric acid remained stable irrespective of level of feed intake. It is suggested that the relative proportion of allantoin:total PM is constant for cattle, buffaloes and yak (85\%) but not valid for other animals since the relative contribution of allantoin to total PM was not constant, depending on the level of exogenous purine absorption.

The daily urinary excretion of creatinine, which is decomposed from creatine and creatine phosphate at constant fractional rates, is fairly constant over a short period of time (Ørskov, 1992). Faichney et al. (1995) stated that the variations in daily excretion of creatinine are largely due to between animal differences and also to the effect of diets. It has been suggested that excretion rate of creatinine is relatively constant in healthy animals and remains independent of level of feed intake (Chen et al., 1995). However, in the present study, the excretion of creatinine, expressed in terms of metabolic body weight, was higher at lower levels of intake. This might be due to increased degradation of phosphocreatine in muscle tissues as also confirmed during the fasting phase of the present experiment. Observed values of creatinine excretion are comparable with those $\left(0.44 \mathrm{mmol} / \mathrm{kgW}^{0.75} / \mathrm{d}\right)$ published for goat fed on diet based on olive cake (Yáñez Ruiz et al., 2004). However, Lindberg (1985) reported higher values in dairy goats $(0.54$ to 0.78 $\mathrm{mmol} / \mathrm{kgW}^{0.75} / \mathrm{d}$ ). In a study in sheep, creatinine excretion rate remained higher for intakes of 0.5 times maintenance when compared with maintenance and above maintenance levels (Liu and McMeniman, 2006). Gonda et al. (1996) observed increased creatinine excretion when the proportion of concentrate was increased in the diet of dairy cows. Under these circumstances, it is not possible to conclude whether these apparent differences are due to the diet or to differences in the 
protein metabolism of the animals. It is conceivable that between breed/species differences in musculature, variations in body weight and dietary regimes could account partly for these discrepancies. PMC index of total urine (Y) showed a linear relation with DOMI $(\mathrm{X}, \mathrm{kg} / \mathrm{d})$ and the resultant equation is as follows: $\mathrm{Y}=$ $57.35 \mathrm{X}+0.51(\mathrm{R} 2=0.72)$.

Microbial nitrogen supply. When feed is identical qualitatively, the efficiency of microbial growth will obviously depend upon the level of intake. Feeding levels had significant effects $(\mathrm{P}<0.05)$ on daily production of $\mathrm{MN}$ as well as the efficiency of MN synthesis. The average values of microbial efficiency (15.79 to $22.34 \mathrm{~g} /$ $\mathrm{kg}$ DOMI) from daily urinary PM measurements are similar to that suggested for cattle and sheep (20.8 g/kg DOMI) on good quality mixed diets (ARC, 1984). When expressed on the basis of DOMR the efficiency of MN followed a similar trend (29.29 to $34.37 \mathrm{~g} / \mathrm{kg}$ DOMR) and the values corroborated well with mean value for microbial synthesis efficiency ( $32 \mathrm{~g} / \mathrm{kg}$ DOMR) suggested by ARC (1984). In a similar study (Chen et al., 1992), a linear increase in efficiency of MN synthesis (12-28.3 g/kg DOMR) with increasing DM intake was observed for sheep. Since microbial protein synthesis is dependent on fermentable OM and ammonia nitrogen supply, it is hoped that the efficiency of synthesis will decrease with the reduction in the feed intake as observed in the present study. Moreover, under field use, this method will replace calculations of microbial yield that are presently used, and thereby increase the accuracy of meeting protein requirement of animals, particularly that of high producing ones.

$P M C$ index. The use of spot urine samples for estimating rumen microbial protein synthesis in field conditions is applicable only if there is a minimal diurnal variation and a high correlation with daily measurements. In the present study the correlation between the daily urinary PM excretion and the PM concentration in spot urine samples collected at $6 \mathrm{~h}$ interval were too low $\left(\mathrm{R}^{2}=0.19\right)$. Interestingly, the values of PMC index in spot urine samples showed a better correlation $\left(\mathrm{R}^{2}=0.70\right)$ with daily urinary PM excretion. In a similar study, Chen et al. (1995) showed that the PMC index is highly correlated $\left(\mathrm{R}^{2}=0.85\right)$ with the daily PM excretion in sheep fed various diets ad libitum. To assess precisely the possibility of using spot urine sampling technique to estimate daily total PM excretion, the correlation between daily urinary PM excretion and PMC index of spot urine samples collected at $6 \mathrm{~h}$ intervals were calculated. The relationship between PMC index in the spot samples collected $12 \mathrm{~h}$ after the morning feed and the daily total $\mathrm{PM}$ excretion $(\mathrm{P}<0.05)$ was the highest $\left(\mathrm{R}^{2}=0.82\right)$. Fujihara et al. (2005) have shown that the PMC index in the spot urine taken 7-8 $\mathrm{h}$ after the morning feed tended to give a better representation of the daily mean in sheep fed at different energy levels, while Chen et al. (1995) observed a better correlation between 7-12 h post-feeding in steers. On contrary, in crossbred bulls PMC index in spot 
urine samples collected at the time of feeding had improved correlation with daily urinary PM excretion, digestible OM intake and DM intake (George et al., 2006). In the present study, the concentration of PM and creatinine in spot urine showed diurnal variation but the concentration of total PM when expressed as molar proportion of creatinine showed less influence of sampling time, thus confirming the observations of previous studies (Chen et al., 1995; George et al., 2006). In contrast, the data of Shingfield and Offer (1998) demonstrated the dependence of PMC index on sampling time. In the present study, PMC index in spot urine samples was highly correlated with daily PM excretion; this feature together with the relative diurnal stability of the index, indicates the validity of using this index as an alternative to the daily PM excretion for the estimation of microbial protein supply.

\section{CONCLUSIONS}

The study revealed that purine metabolites:creatinine index calculated from urinary spot samples correlates with daily urinary purine metabolites excretion and thus can be used as an indicator of microbial protein supply in goats under field conditions.

\section{ACKNOWLEDGEMENTS}

The first author is indebted to UGC, New Delhi for providing financial assistance in the form of senior research fellowship.

\section{REFERENCES}

Agabriel J., Petit M., Ollier A., Chilliard Y., 1995. Effect of underfeeding on body reserves variations and on energy efficiency of lactating Crolais cows. Ann. Zoot. 44, 317

AOAC, 1995. Association of Official Analytical Chemists, Official Methods of Analysis. 16 $6^{\text {th }}$ Edition. Washington, DC

ARC, 1984. The Nutrient Requirements of Ruminant Livestock, No. 1. Commonwealth Agricultural Bureaux, pp. 3-18

Balcells J., Fondevila M., Gowda J.A., Castrillo C., Surra J.C.E., 1993. Urinary excretion of purine derivatives and nitrogen in sheep given straw supplemented with different sources of carbohydrates. Anim. Prod. 57, 287-292

Chen X.B., Gomes M.J., 1992. Estimation of microbial protein supply to sheep and cattle based on urinary excretion of purine derivatives - An overview of the technical details. Rowett Research Institue, University of Aberdeen (UK) 
Chen X.B., Grubic G., Ørskov E.R., Osuji P., 1992. Effect of feeding frequency on diurnal variation in plasma and urinary purine derivatives in steers. Anim. Prod. 55, 185-191

Chen X.B., Hovell F.D. DeB., Ørskov E.R., Brown D.S., 1990a. Excretion of purine derivatives by ruminants: effect of exogenous nucleic acid supply on purine derivatives excretion in sheep. Brit. J. Nutr. 63, 131-142

Chen X.B., Mejia A.T., Kyle D.J., Ørskov E.R., 1995. Evaluation of the use of the purine derivative:creatinine ratio in spot urine and plasma samples as an index of microbial protein supply in ruminants: studies in sheep. J. Agr. Sci. 125, 137-143

Chen X.B., Ørskov E.R., Hovell F.D. DeB., 1990. Excretion of purine derivatives by ruminants: endogenous excretion, differences between cattle and sheep. Brit. J. Nutr. 63, 121-129

Czauderna M., Kowalczyk J., 2000. Quantification of allantoin, uric acid, xanthine and hypoxanthine in ovine urine by high-performance liquid chromatography and photodiode array detection. J. Chromatogr. B 744, 129-138

Czauderna M., Kowalczyk J., 2004. Simultaneous determination of purine metabolites in ovine urine and blood plasma by high-performance liquid chromatography. J. Anim. Feed Sci. 13, Suppl. 1, 55-58

Daniels Z.M., Chen X.B., Kyle D.J., Sinclair K., Ørskov E.R., 1994. Purine derivatives in urine and plasma of lactating cows given different levels of food intake. Anim. Prod. 58, 483 (Abstr.)

Dipu M.T., George S.K., Singh P., Verma A.K., Mehra U.R., 2006. Measurement of microbial protein supply in Murrah buffaloes (Bubalus bubalis) using urinary purine derivatives excretion and PDC index. Asian-Austr. J. Anim. Sci. 19, 347-355

Faichney G.J., Welch R.J., Brown G.H., 1995. Prediction of the excretion of allantoin and total purine derivatives by sheep from the creatinine coefficient. J. Agr. Sci. 125, 425-428

Fujihara T., Shem M.N., Hirano T., 2003. Urinary excretion and blood plasma allantoin in lambs and young goats starved and refed with a purine free diet. J. Agr. Sci. 140, 107-111

Fujihara T., Shem M.N., Nakamura K., 2005. Effect of dietary energy levels on urinary excretion of purine derivatives in sheep. Anim. Sci. J. 76, 441-445

George S.K., Dipu M.T., Mehra U.R., Verma A.K., Singh P., 2006. Influence of levels of feed intake on concentration of purine derivatives in urinary spot samples and microbial nitrogen supply in crossbred bulls. Asian-Austr. J. Anim. Sci. 19, 1291-1297

Gonda H.L., Emanuelson M., Murphy M., 1996. The effect of roughage to concentrate ratio in the diet on nitrogen and purine metabolism in dairy cows. Anim. Feed Sci. Tech. 64, 27-42

IAEA-TECDOC-945, 1997. Estimation of rumen microbial protein production from purine derivatives in urine. International Atomic Energy Agency, Vienna

Laurent F., Blanchart G., Vignon B., 1983. Relationship between the urinary excretion of allantoin and nitrogen in lactating goats. In: Proceedings of IV ${ }^{\text {th }}$ Symposium International de Metabolisme et Nutrition Azotes, Vol . 2, pp. 175-178

Liang J. B., Matsumoto M., Young, B.A., 1994. Purine derivative excretion and ruminal microbial yield in Malaysian cattle and swamp buffalo. Anim. Feed Sci. Tech. 47, 189-199

Lindberg J.E., 1985. Urinary allantoin excretion and digestible organic matter intake in dairy goats. Swedish J. Agr. Res. 15, 31-37

Lindberg J.E., 1989. Nitrogen metabolism and urinary excretion of purines in goat kids. Brit. J. Nutr. 61, 309-321

Liu Z.J., McMeniman N.P., 2006. Effect of nutrition level and diets on creatinine excretion by sheep. Small Ruminant Res. 63, 265-273

Mota M., Balcells J., Ozdemir Baber N.H., Boluktepe S., Belengur A., 2008. Modelling purine derivative excretion in dairy goats: endogenous excretion and the relationship between duodenal input and urinary output. Animal 2, 44-51 
NRC, 1981. Nutrient Requirements of Goats: Angora, Dairy and Meat Goats in Temperate and Tropical Countries. National Research Council. Washington, DC

Shingfield K.J., Offer N.W., 1998. Evaluation of the spot urine sampling technique to assess urinary purine derivative excretion in lactating dairy cows. Anim. Sci. 66, 557-568

Thanh V.T.K., Ørskov E.R., Susmel P., 2009. Physiological mechanism of low purine derivative excretion in urine of buffaloes compared with Bos taurus cattle. Anim. Prod. Sci. 49, 994-997

Topps J.H., Elliot R.C., 1965. Relationships between concentrations of ruminal nucleic acid and excretion of purine derivatives by sheep. Nature 205, 498-499

Yáñez Ruiz D.R., Moumen A., Martin Garcia A.I., Molina Alcaide E., 2004. Ruminal fermentation and degradation patterns, protozoa population and urinary purine derivatives excretion in goats and wethers fed diets based on two stage olive cake: Effect of PEG supply. J. Anim. Sci. 82, 2023-2032

Young E.G., Conway C.F., 1942. On the estimation of allantoin by Rimini-Schryver reaction. J.

Biol. Chem. 142, 839-852 